\title{
Estimation of chlorophyll in Quercus leaves using a portable chlorophyll meter: effects of species and leaf age
}

\author{
Fernando Silla*, Ana GonZÁlez-Gil, Ma Esther GonZÁleZ-MolinA, Sonia MediaviLla, \\ Alfonso ESCUDERO
}

Área de Ecología, Facultad de Biología, Universidad de Salamanca, Campus Unamuno 37007 Salamanca, Spain

(Received 15 April 2009; accepted 6 July 2009)

Keywords:

Quercus sp. /

leaf chlorophyll content /

CCM-200 chlorophyll meter /

leaf age /

LMA

Mots-clés :

Quercus sp. /

teneur en chlorophylle des feuilles /

chlorophyllomètre CCM-200 /

âge des feuilles /

LMA

\begin{abstract}
- The potential of a chlorophyll meter (CCM-200, Opti-Sciences, Tyngsboro, MA, USA) for the estimation of total leaf chlorophyll contents was evaluated in leaves of different developmental stages for Quercus pyrenaica Willd., Q. faginea Lam., Q. suber L. and Q. ilex L. subsp. ballota (Desf.) Samp.

- For all species and leaf stages, a strong non-linear relationship $(P<0.0001)$ was found between the chlorophyll content index (CCI) and leaf chlorophyll content per unit area. In all species, the slope of the CCI-chlorophyll content relationship varied during leaf development, suggesting that caution should be exercised when using the CCM-200, since the interpretation of CCI readings should be limited to samples of similar leaf age. Also, the data indicate that the models should also be speciesspecific, owing to differences in the intercept and/or slope of the equations.

- The addition of fresh LMA as a complementary parameter improved the accuracy of chlorophyll estimation in non-species-specific equations to a considerable extent when leaf samples of similar development were considered.

- After due consideration, it may be concluded that the CCM-200 chlorophyll meter is a reliable method for acquiring an estimation of chlorophyll contents in Mediterranean Quercus species, with potential use as an effective tool in forest management.
\end{abstract}

Résumé - Estimation de la chlorophylle dans les feuilles de Quercus en utilisant un chlorophyllomètre portable : effets de l'espèce et de l'âge des feuilles.

- Le potentiel d'un chlorophyllomètre (CCM-200, Opti-Sciences, Tyngsboro, MA, USA) pour l'estimation du contenu total des feuilles en chlorophylle a été évalué dans des feuilles à différents stades de développement chez Quercus pyrenaica Willd., Q. faginea Lamb. Q. suber L. et $Q$. ilex L. subsp. ballota (Desf.) Samp.

- Pour toutes les espèces et les feuilles à différents stades, une forte relation non linéaire $(P<0,0001)$ a été trouvée entre l'index de teneur en chlorophylle (CCI) et la teneur en chlorophylle des feuilles par unité de surface. Chez toutes les espèces, la pente de la relation CCI-teneur en chlorophylle a varié avec le développement de la feuille, ce qui suggère que la prudence est de mise lors de l'utilisation du CCM-200,puisque l'interprétation des indications du CCI devraient être limitées à des échantillons de feuilles d'âge similaire. Aussi, les données indiquent que les modèles devraient également être spécifiques à l'espèce, en raison des différences dans l'interception et/ou la pente des équations.

- L'ajout de nouvelles LMA en tant que paramètre complémentaire a amélioré la précision de l'estimation de la chlorophylle dans les équations non spécifiques de l'espèce, et ceci dans une large mesure lorsque des échantillons de feuilles de développement similaires ont été examinés.

- Après mûre réflexion, il peut être conclu que le chlorophyllomètre CCM-200 est une méthode fiable pour l'acquisition d'une estimation de la teneur en chlorophylle des espèces méditerranéennes de Quercus, avec la possibilité de l'utiliser comme un outil efficace pour la gestion des forêts.

\footnotetext{
*Corresponding author: fsilla@usal.es
} 


\section{INTRODUCTION}

Chlorophylls ( $a$ and $b$ ) are the most important leaf antenna pigments, and the absorption of solar radiation is the first stage in the photosynthetic pathway. Thus, the leaf chlorophyll content is one of the most significant parameters related to the physiological status of plants. Estimations of chlorophyll contents and related chlorophyll parameters have practical implications since they can be used as an index of nutrient status (Berg and Perkins, 2004; Chang and Robinson, 2003; Moran et al., 2000; Wood et al., 1992), physiological stress (Daas et al., 2008; Datt, 1999; Neufeld et al., 2006; Peguero-Pina et al., 2008; Peñuelas and Filella, 1998) and changes in abiotic factors (Abadía et al., 1996; Gratani et al., 1996).

Fast and non-destructive methods for chlorophyll estimation are based on the reflectance and/or absorbance of light by leaf pigments. Portable chlorophyll meters measure the transmittance of light by leaves at two different wavelengths: red $(650-660 \mathrm{~nm})$ and near-infrared $(930-940 \mathrm{~nm})$. Red light is strongly absorbed by chlorophylls, and its absorption is evidently correlated with the chlorophyll content, whereas the calculation of near-infrared absorption is used as a "reference value" to adjust for differences in leaf structure (Markwell et al., 1995). Thus, chlorophyll meters provide a "chlorophyll index" that is strongly correlated with the leaf chlorophyll content. In recent decades, chlorophyll meters have been increasingly used in the horticultural sciences as an effective management tool for evaluating nutrient and stress status, and more than 200 scientific studies reporting their usefulness have been published. However, in the field of forestry, research exploring the potential of chlorophyll meters has been more limited, despite significant correlations between chlorophyll indices and chlorophyll and/or $\mathrm{N}$ contents (Berg and Perkins, 2004; Chang and Robinson, 2003; Pinkard et al., 2006; Richardson et al., 2002; Sibley et al., 1996; Uddling et al., 2007).

Previous studies with chlorophyll meters have shown that an adequate calibration between the readings of such meters and actual leaf chlorophyll content is necessary. In many cases, non-linear equations have been used to explain the relationship between the two parameters better due to non-uniform distribution of chlorophyll and differential scattering and reflection of light at the wavelengths used (Markwell et al., 1995; Monge and Bugbee, 1992; Uddling et al., 2007). In this sense, several studies have reported that calibration should be speciesspecific (Castelli et al., 1996; Pinkard et al., 2006; Uddling et al., 2007; Yamamoto et al., 2002), and that it may even be affected by growing conditions (Campbell et al., 1990; Jifon et al., 2005). Another issue, although little addressed (Thompson et al., 1996), is that leaf structural parameters (LMA, tissue density, water content, etc.) change with leaf age. As leaf optical properties are likely modified by changes in structural parameters, it could be expected that the relationship between chlorophyll meter readings and chlorophyll contents will be affected by leaf age.

In the present study, we set up experiments to establish the ability of the hand-held CCM-200 chlorophyll meter (OptiSciences, Tyngsboro, MA, USA) to accurately estimate the chlorophyll content in leaves of Quercus species with contrasting leaf longevities, and its use as an accessory tool in forest management. Quercus species, together with Pinus species, are dominant in Mediterranean forests, and to our knowledge, no calibrations have been established previously. The objectives of the present work were: (1) to calibrate the CCM-200 to estimate total chlorophyll contents in Quercus species; (2) to determine whether the relationship between the CCM-200 index and chlorophyll is the same throughout the growing season within each species; (3) to establish whether the calibration differs between Quercus species; and (4) to analyze the improvement in chlorophyll estimation when fresh LMA is added as an explanatory variable.

\section{MATERIAL AND METHODS}

\subsection{Species and study site}

Four Mediterranean Quercus species with contrasting leaf longevities (and associated leaf properties) were selected. Q. ilex L. subsp. ballota (Desf.) Samp. is a typical evergreen with a mean leaf longevity of 24-25 months. Q. suber L. is an evergreen species with a mean leaf life span of 12-13 months that loses its old leaf cohort during the budbreak of the new leaf cohort. $Q$. faginea Lam. is a marcescent species with a mean leaf longevity of 8-9 months. $Q$. pyrenaica Willd. is a deciduous species with a mean leaf life span of 6-7 months (Mediavilla and Escudero, 2003). The study site was a managed savannah ("dehesa") located in Valdelosa ( $41^{\circ} 09^{\prime} \mathrm{N}, 5^{\circ} 47^{\prime} \mathrm{W}, 830 \mathrm{~m}$ a.s.1.) in the province of Salamanca, Spain, where the four Quercus species coexist. The closest weather station receives a mean annual precipitation of $460 \mathrm{~mm}$.

\subsection{Sampling design}

Leaves were sampled at three stages of leaf development: (1) young leaves of one month of age after budbreak, which were sampled during mid-May for $Q$. faginea and $Q$. pyrenaica, early June for $Q$. ilex, and mid-July for $Q$. suber; (2) fully expanded leaves, which were sampled during late June for $Q$. faginea and $Q$. pyrenaica, mid-July for $Q$. ilex, and November for $Q$. suber; and (3) mature and pre-senescent leaves, most green and healthy, but a few leaves showed early signs of chlorophyll degradation, which were sampled during late October for $Q$. faginea and $Q$. pyrenaica, and early May for $Q$. ilex and $Q$. suber.

We randomly sampled 30 leaves from 8-12 trees per species and leaf stage. The leaves were removed from the trees and measurements were taken with a CCM-200 chlorophyll meter (Opti-Sciences, Tyngsboro, MA, USA). The CCM-200 calculates the chlorophyll content index $(\mathrm{CCI})$ as the ratio between leaf transmission percentages at $931 \mathrm{~nm}$ and $653 \mathrm{~nm}$ (http://www.apogee-inst.com/CCM_techinfo. $\mathrm{htm})$. Absorbance by chlorophyll is negligible at $931 \mathrm{~nm}$ and is used as a reference wavelength since some photons at $653 \mathrm{~nm}$ are absorbed by molecules other than chlorophyll. Leaf area measurement of the CCM-200 meter is $0.71 \mathrm{~cm}^{2}$. Between 4 and 8 measurements were taken per leaf. Leaf area varied considerably both within and between species (four and ten times, respectively), and accordingly, a greater number of measurements was taken in bigger leaves. The measurements were averaged to provide a single chlorophyll content index 

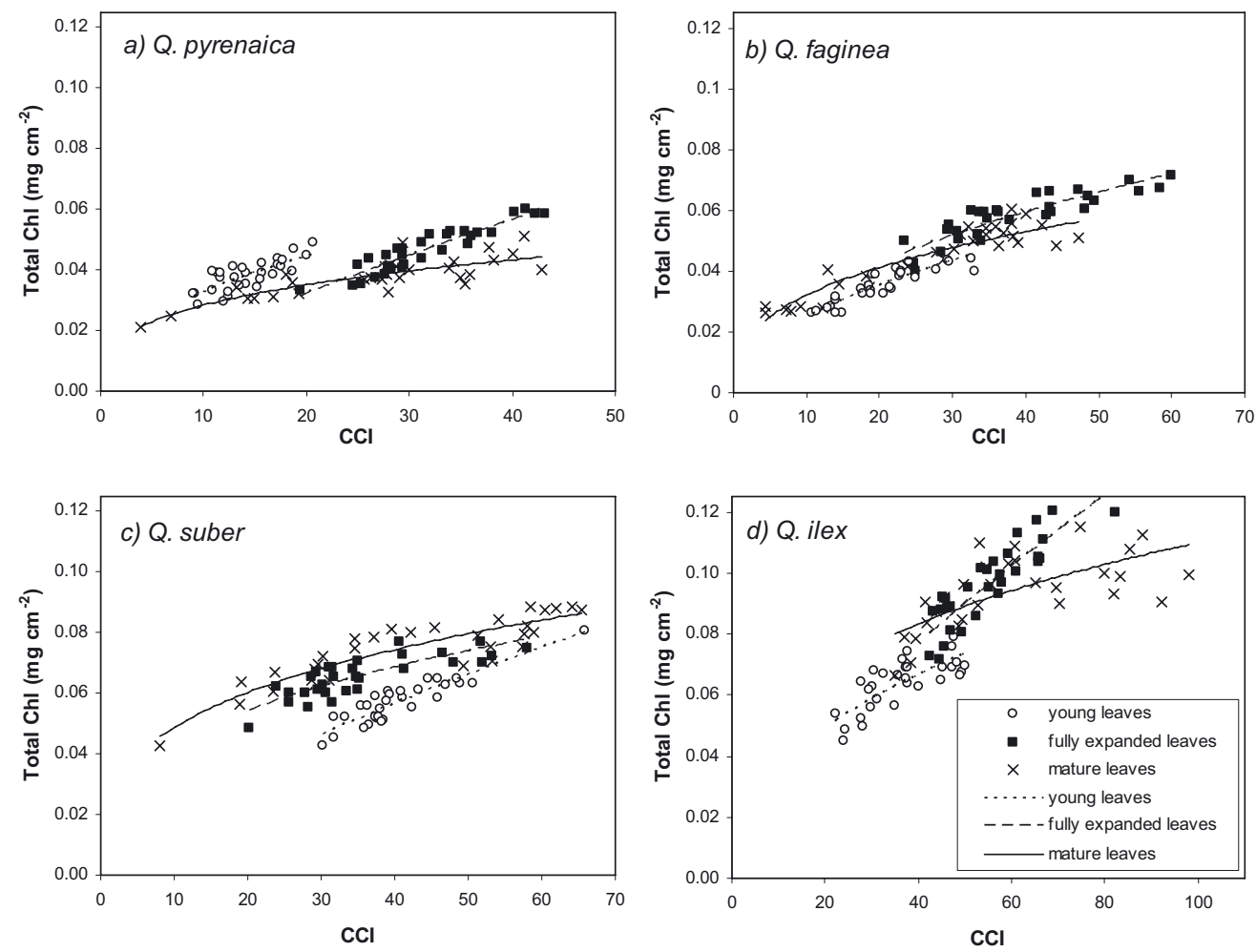

Figure 1. Relationship between the CCI and total chlorophyll content (total Chl, $\mathrm{mg} \mathrm{cm}^{-2}$ ) in the four Quercus species. Lines are predicted values from the log-transformed functions for each leaf stage (Tab. I).

(CCI) per leaf. The CCM sensor was placed randomly on the leaf mesophyll, avoiding the mid-vein.

Leaves were placed in plastic bags and carried to the laboratory in an icebox, and were kept frozen at $-20{ }^{\circ} \mathrm{C}$ for no longer than $2 \mathrm{~d}$ before processing. The area was measured on each fresh leaf using a leaf-area meter (Delta-T Mod. DIAS II, Delta-T Devices Ltd., Cambridge, UK), after which the leaf was weighed on a precision balance (Sartorius CP 124S, DWS, IL, USA). Depending on leaf area, from 3-5 disks (each $0.45 \mathrm{~cm}^{2}$ ) per leaf were extracted (avoiding the midvein) with a punch and weighed. The leaf remains of each sample were dried for $24 \mathrm{~h}$ at $60{ }^{\circ} \mathrm{C}$ and weighed to obtain an estimate of the leaf mass per area (LMA).

Chlorophyll was extracted with the DMSO method (Barnes et al., 1992; Hiscox and Israelstam, 1979; Tait and Hik, 2003). Each sample was incubated in a glass vial with $10 \mathrm{~mL}$ of DMSO in a waterbath at $65^{\circ} \mathrm{C}$ for $5 \mathrm{~h}$ in the dark. Samples were transferred to disposable polystyrene cuvettes, and absorbance was measured at 649 and $665 \mathrm{~nm}$ with a spectrophotometer (wavelength range 190-1100 nm, spectral bandwidth $2 \mathrm{~nm}$, wavelength accuracy $\pm 1 \mathrm{~nm}$; model PGT60, PG Instruments Limited, UK). Total chlorophyll (chlorophyll $a+b)$ contents per unit leaf area were estimated using Wellburn's (1994) equation for DMSO and spectrophotometers with a resolution range of $1-4 \mathrm{~nm}$ : tot $\mathrm{Chl}\left(\mu \mathrm{g} \mathrm{ml}^{-1}\right)=18.54 A_{649}+6.87 A_{665}$. Although the classic Arnon equations have been proposed for DMSO extracts (Hiscox and Israelstam, 1979; Richardson et al., 2002), they have fallen out of favor owing to the detection of significant inaccuracies (Barnes et al., 1992; Porra, 2002). The chlorophyll concentrations of the extracts calculated from this equation were then converted into leaf chlorophyll contents per unit area.

\subsection{Data analysis}

To explore the relationship between CCI readings and chlorophyll data, several models previously discussed in the literature were used: linear, exponential, log-transformed and second-order polynomial functions (Berg and Perkins, 2004; Pinkard et al., 2006; Richardson et al., 2002; Uddling et al., 2007). Both log-transformed and secondorder polynomial functions provided the best explanation of the data, with very similar results. The log-transformed function was selected because data linearization is an assumption of ANCOVA analysis (Gotelli and Ellison, 2004; Sokal and Rohlf, 1995). ANCOVA was carried out with interaction analysis to test for homogeneity of the Yintercepts and slopes of the regression lines between sampling dates across species, and between species across sampling dates (Gotelli and Ellison, 2004; Sokal and Rohlf, 1995). Multiple regression models were performed using CCI and fresh LMA as independent variables, and the chlorophyll content as the dependent variable. Water content and dry LMA were used as alternative variables, but the results of the analyses were poorer, and for clarity and simplicity they are not shown here. ANOVA analyses were used to test for differences in fresh LMA, and the data were transformed logarithmically (base10) after they had been tested for normality (Shapiro-Wilk W test), which normalized the data distribution and stabilized the variances in the error terms (Sokal and Rohlf, 1995). Analyses were performed using the JMP 5.0 statistical software (SAS Institute, Cary, NC, USA). 
Table I. Calibration equations of the four Quercus species for each leaf stage and the three stages combined. The equations convert the CCI value into theestimated total chlorophyll content per unit area $\left(\mathrm{mg} \mathrm{cm}^{-2}\right)$.

\begin{tabular}{|c|c|c|c|c|c|}
\hline Species & Leaf stage & $n$ & Equation & $P$ & $r^{2}$ \\
\hline \multirow[t]{4}{*}{ Q. pyrenaica } & Young leaves & 30 & $\log (\mathrm{Chl})=-4.439+0.442 \log (\mathrm{CCI})$ & $<0.0001$ & 0.58 \\
\hline & Fully expanded leaves & 30 & $\log (\mathrm{Chl})=-1.286+0.818 \log (\mathrm{CCI})$ & $<0.0001$ & 0.85 \\
\hline & Mature leaves & 30 & $\log (\mathrm{Chl})=-4.265+0.305 \log (\mathrm{CCI})$ & $<0.0001$ & 0.77 \\
\hline & All combined & 90 & $\log (\mathrm{Chl})=-4.106+0.289 \log (\mathrm{CCI})$ & $<0.0001$ & 0.56 \\
\hline \multirow[t]{4}{*}{ Q. faginea } & Young leaves & 30 & $\log (\mathrm{Chl})=-4.852+0.503 \log (\mathrm{CCI})$ & $<0.0001$ & 0.83 \\
\hline & Fully expanded leaves & 30 & $\log (\mathrm{Chl})=-4.578+0.475 \log (\mathrm{CCI})$ & $<0.0001$ & 0.77 \\
\hline & Mature leaves & 30 & $\log (\mathrm{Chl})=-4.269+0.360 \log (\mathrm{CCI})$ & $<0.0001$ & 0.88 \\
\hline & All combined & 90 & $\log (\mathrm{Chl})=-4.679+0.482 \log (\mathrm{CCI})$ & $<0.0001$ & 0.82 \\
\hline \multirow[t]{4}{*}{ Q. suber } & Young leaves & 30 & $\log (\mathrm{Chl})=-5.453+0.699 \log (\mathrm{CCI})$ & $<0.0001$ & 0.79 \\
\hline & Fully expanded leaves & 30 & $\log (\mathrm{Chl})=-3.923+0.338 \log (\mathrm{CCI})$ & $<0.0001$ & 0.66 \\
\hline & Mature leaves & 30 & $\log (\mathrm{Chl})=-3.720+0.304 \log (\mathrm{CCI})$ & $<0.0001$ & 0.83 \\
\hline & All combined & 90 & $\log (\mathrm{Chl})=-3.880+0.315 \log (\mathrm{CCI})$ & $<0.0001$ & 0.37 \\
\hline \multirow[t]{4}{*}{ Q. ilex } & Young leaves & 30 & $\log (\mathrm{Chl})=-4.335+0.441 \log (\mathrm{CCI})$ & $<0.0001$ & 0.60 \\
\hline & Fully expanded leaves & 30 & $\log (\mathrm{Chl})=-0.581+0.709 \log (\mathrm{CCI})$ & $<0.0001$ & 0.75 \\
\hline & Mature leaves & 30 & $\log (\mathrm{Chl})=-3.600+0.302 \log (\mathrm{CCI})$ & $<0.0001$ & 0.48 \\
\hline & All combined & 90 & $\log (\mathrm{Chl})=-4.885+0.617 \log (\mathrm{CCI})$ & $<0.0001$ & 0.73 \\
\hline
\end{tabular}

\section{RESULTS}

The CMM-200 afforded high readings for the Quercus species, with mean values over the entire season of $24.3 \pm 1.1,29.0 \pm 1.3$, $39.6 \pm 1.2$ and $50.7 \pm 1.7$ (data indicate means $\pm \mathrm{SE}, n=90$ ) for $Q$. pyrenaica, $Q$. faginea, $Q$. suber and $Q$. ilex, respectively. In all cases a strong relationship $(P<0.0001)$ was observed between CCI readings and total chlorophyll content per unit area (Fig. 1 and Tab. I). When this relationship per leaf stage and species was considered, $Q$. faginea provided the most satisfactory results, with much of the variance explained $\left(r^{2}=0.77-0.88\right)$ in the three leaf stages by the logtransformed model (Tab. I). Q. pyrenaica $\left(r^{2}=0.58-0.85\right)$ and $Q$. suber $\left(r^{2}=0.66-0.83\right)$ showed good-quality fitting results, $Q$. ilex $\left(r^{2}=0.48-0.75\right)$ exhibiting the poorest fitting performance (Tab. I). $Q$. ilex generated the highest CCI values (up to 98), especially in the oldest leaf stage (Fig. 1). In fact, there was a considerable dispersion of data above $70 \mathrm{CCI}$ units, and when these data were eliminated, the coefficient of determination increased from 0.48 to 0.78 $(n=20)$ in the mature leaf stage. The relationship was equally significant $(P<0.0001)$ when the data of the three leaf stages of each species were pooled (Tab. I). Q. faginea and $Q$. ilex showed high coefficients of determination; $Q$. pyrenaica an intermediate result, and $Q$. suber showed a poor fit (Tab. I). However, in all four Quercus species the interaction between CCI and leaf stage was highly significant (Tab. II), indicating that the CCI- chlorophyll content relationship varied during leaf development (Fig. 1).

Table III shows the results when the data for the four Quercus species were pooled for each leaf stage. In all cases, the relationship was highly significant $(P<0.0001)$, and the variance explained by the models was also high $\left(r^{2}=0.70-0.77\right)$. Fully expanded leaves showed the best averaged results $\left(r^{2}=0.77\right)$ for use of the CCM200. Mature leaves also afforded good results, with a mean coefficient of determination of 0.74 , although if the CCI readings above 70 recorded in $Q$. ilex are ignored, the mean coefficient of determination is improved up to 0.81 (data not shown). Young leaves ranked lower $\left(r^{2}=0.70\right.$; Tab. III), owing to the low performance obtained for $Q$. pyrenaica and $Q$. ilex (Tab. I). Except for the fully expanded leaves, the interaction between species and the CCI was not significant (Tab. IV), indicating that the slope of the CCI- chlorophyll
Table II. Probability values $(P)$ of the ANCOVA analyses to test for differences in the Y-intercept and slope of the equations of the three leaf stages in each species ( $n=30$ per leaf stage in each species). A significant interaction indicates differences in slope; only if the interaction is not significant can differences in the Y-intercept (leaf stage factor) be interpreted.

\begin{tabular}{lccc}
\hline & Leaf stage & CCI & Interaction \\
\hline Q. pyrenaica & $<0.0001$ & $<0.0001$ & $<0.0001$ \\
Q. faginea & $<0.0001$ & $<0.0001$ & 0.0106 \\
Q. suber & $<0.0001$ & $<0.0001$ & $<0.0001$ \\
Q. ilex & $<0.0001$ & $<0.0001$ & 0.0009 \\
\hline
\end{tabular}

Table III. Calibration equations for each leaf stage when the data from the four Quercus species were pooled. The equations convert the CCI value into the estimated total chlorophyll content per unit area $\left(\mathrm{mg} \mathrm{cm}^{-2}\right)$.

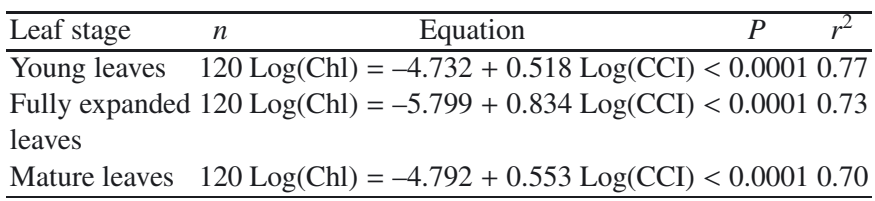

content relationship was the same, but with different intercepts for each species (since the species variable was statistically significant, Tab. V).

Figure 2 shows the changes in fresh LMA during the leaf stages, and the contribution of dry LMA and water content to fresh LMA. In $Q$. pyrenaica and $Q$. faginea, fresh LMA was greater in young leaves owing to their higher water content, even though dry LMA increased with leaf age. However, in $Q$. suber, the statistically significant increase in fresh LMA paralleled the increase in dry LMA. In $Q$. ilex, no differences in fresh LMA due to compensatory changes in dry LMA and water content were detected. When fresh LMA was added as an additional explanatory variable to the CCI in the multiple regression equations of the species-specific models, only $Q$. pyrenaica and $Q$. suber showed an improvement in the accurateness of 
Table V. Multiple regression models in which fresh LMA was included as an additional explanatory variable to CCI. The data on the three leaf stages of each species were pooled. The equations convert the CCI and fresh LMA $\left(\mathrm{g} \mathrm{m}^{-2}\right)$ values into the estimated total chlorophyll content per unit area $\left(\mathrm{mg} \mathrm{cm}^{-2}\right)$. The significance values of both parameters (CCI and fresh LMA) are shown.

\begin{tabular}{lccccc}
\hline Species & $n$ & Equation & CCI & LMA & $r^{2}$ \\
\hline Q. pyrenaica & 90 & $\log (\mathrm{Chl})=-2.005+0.438 \log (\mathrm{CCI})+0.00077 \mathrm{LMA}$ & $<0.0001$ & $<0.0001$ \\
Q. faginea & 90 & $\log (\mathrm{Chl})=-2.009+0.484 \log (\mathrm{CCI})-0.00012 \mathrm{LMA}$ & $<0.0001$ & 0.3678 \\
Q. suber & 90 & $\log (\mathrm{Chl})=-1.778+0.250 \log (\mathrm{CCI})+0.00073 \mathrm{LMA}$ & $<0.0001$ & $<0.0001$ \\
Q. ilex & 90 & $\log (\mathrm{Chl})=-2.076+0.627 \log (\mathrm{CCI})-0.00017 \mathrm{LMA}$ & $<0.0001$ & 0.1595 & 0.79 \\
\hline
\end{tabular}

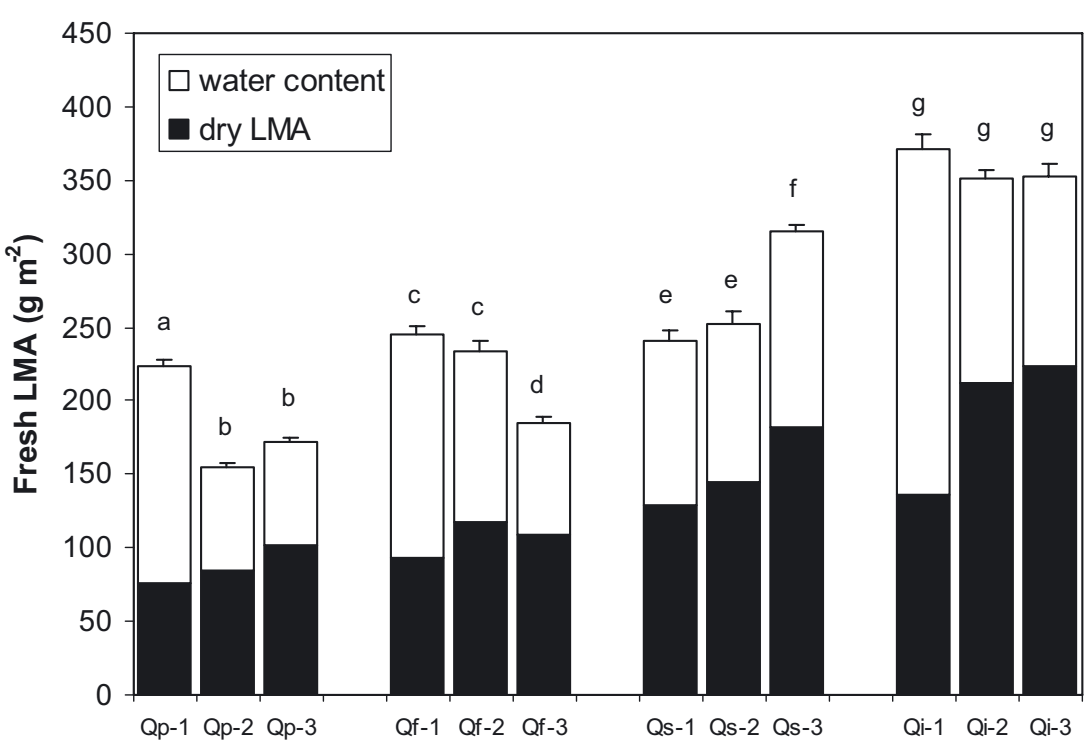

Figure 2. Fresh LMA during the leaf stages in the four Quercus species. Different letters indicate significant differences between leaf stages within species at $P<0.05$. Qp: $Q$. pyrenaica, Qf: $Q$. faginea, Qs: $Q$. suber, Qi: $Q$. ilex; 1: young leaves, 2: fully developed leaves, 3: mature leaves.

Table IV. Probability values $(P)$ of the ANCOVA analyses to test for differences in the Y-intercept and slope of the equations of the four Quercus species when each leaf stage was considered separately ( $n=30$ per species in each leaf stage). A significant interaction indicates differences in slope; only if the interaction is not significant can differences in the Y-intercept (species factor) be interpreted.

\begin{tabular}{lccc}
\hline & Species & CCI & Interaction \\
\hline Young leaves & $<0.0001$ & $<0.0001$ & 0.0815 \\
Fully expanded leaves & $<0.0001$ & $<0.0001$ & $<0.0001$ \\
Mature leaves & $<0.0001$ & $<0.0001$ & 0.3706 \\
\hline
\end{tabular}

chlorophyll content predictions (Tab. V). On the other hand, when leaf development models were considered, the addition of fresh LMA in multiple regression models noticeably improved the coefficients of determination with respect to simple regression equations in the three leaf stages $\left(r^{2}=0.82-0.92\right.$, Tab. VI).

\section{DISCUSSION}

The present findings show that the CCM-200 provides good estimates of chlorophyll content in the Quercus species studied. The best results were obtained with $Q$. faginea, with high coefficients of determination on all sampling dates. The CCM-200 worked satisfactorily in the other three species, but performance was more variable, depending on the leaf stage (Tab. I). The relationship between CCI values and chlorophyll values was clearly non-linear, and it was best explained by the log-log model, as chlorophyll contents showed a tendency to stabilize with high CCM-200 readings (Berg and Perkins, 2004; Richardson et al., 2002, this study). One potential limitation of absorbance meters is that at high levels of chlorophyll, so much of the $650-660 \mathrm{~nm}$ light is absorbed by the leaf that little remains to be transmitted and measured on the far side (Richardson et al., 2002), and likely CCI values are mainly determined by differences in transmittance at 930-940 $\mathrm{nm}$. Other common chlorophyll meters, such as the Minolta SPAD model, use linear (Gratani, 1992; Neufeld et al., 2006; Yamamoto et al., 2002; Wang et al., 2004) or exponential equations (Markwell et al., 1995; Monje and Bugbee, 1992; Uddling et al., 2007). Although both meters use similar wavelengths, chlorophyll indices are calculated differently, and relationships between the two meters involve third-order polynomial models (Richardson et al., 2002).

Our data show that the relationship between CCI and chlorophyll content depends on leaf age, since the interaction between CCI and leaf stage was significant in all species (Tab. II). This suggests that caution should be used when using the CCM-200, since the interpretation of CCI readings should be limited to leaf samples of similar leaf development. Although little considered, the influence of leaf age on the calibration of chlorophyll meters is not a surprising result. First, previous works have shown that calibration of chlorophyll meters is linked to differences in leaf optical properties related to leaf anatomy 
Table VI. Multiple regression models of each leaf stage. Fresh LMA was included as an additional explanatory variable to CCI and the data of the four Quercus species were pooled. The equations convert the CCI and fresh LMA ( $\mathrm{g} \mathrm{m}^{-2}$ ) values into the estimated total chlorophyll content per unit area $\left(\mathrm{mg} \mathrm{cm}^{-2}\right)$. The significance values of both parameters (CCI and fresh LMA) are shown.

\begin{tabular}{|c|c|c|c|c|c|}
\hline Leaf stage & $n$ & Equation & CCI & LMA & $r^{2}$ \\
\hline Young leaves & 120 & $\log (\mathrm{Chl})=-2.064+0.438 \log (\mathrm{CCI})+0.00045 \mathrm{LMA}$ & $<0.0001$ & $<0.0001$ & 0.82 \\
\hline Fully expanded leaves & 120 & $\log (\mathrm{Chl})=-2.183+0.495 \log (\mathrm{CCI})+0.00082 \mathrm{LMA}$ & $<0.0001$ & $<0.0001$ & 0.85 \\
\hline Mature leaves & 120 & $\log (\mathrm{Chl})=-2.071+0.336 \log (\mathrm{CCI})+0.00125 \mathrm{LMA}$ & $<0.0001$ & $<0.0001$ & 0.92 \\
\hline
\end{tabular}

(Monje and Bugbee, 1992; Thompson et al., 1996). Second, chloroplasts can modify their orientation in response to incident irradiance (Haupt and Scheuerlein, 1990), and seasonal changes in irradiance could affect chlorophyll meter readings, as reported for the natural night-day-night cycle (Hoel and Solhaug, 1998). Accordingly, leaf structural changes that affect absorption, transmission and scattering of light across the leaf could provide different CCI readings even though the chlorophyll content per unit area has not changed. In fact, fresh LMA addition explains some of the residual variance not accounted for by CCI readings in $Q$. suber and $Q$. pyrenaica, as shown by the multiple regression models (Tab. V).

Likewise, the equations were found to be species-specific when leaves of similar age were considered (Castelli et al., 1996; Pinkard et al., 2006). When the data for the four species were pooled per leaf stage, regression residuals revealed a positive statistical correlation with fresh LMA in all cases $(P<0.01$, data not shown). Positive residuals were associated with high fresh LMA, likely due to a strongly reduced leaf transmission at $931 \mathrm{~nm}$, which generated low CCI readings for a specific chlorophyll content, and vice versa (since $\mathrm{CCI}$ is the ratio between leaf transmission at $931 \mathrm{~nm}$ and $653 \mathrm{~nm}$ ). Thus, the addition of fresh LMA as a second parameter improved the variance explained by multiple regression models with respect to simple regression models, especially in the mature leaves, where the same equation accounted for most of the variation in the data for the four Quercus species (Tab. VI).

Although the statistical relationships between CCI and chlorophyll content observed here were in all cases highly significant, the variance explained by the models used was somewhat lower than in most of the species analyzed in other studies (Pinkard et al., 2006; Richardson et al., 2002; Uddling et al., 2007). This is because the performance of chlorophyll meters has been shown to decrease at high chlorophyll indices (Berg and Perkins, 2004; Monje and Bugbee, 1992; Richardson et al., 2002), and the Quercus species studied here showed high CCI readings, with mean CCI values higher than the upper readings observed in other tree species when the same chlorophyll meter was used (Berg and Perkins, 2004; Richardson et al., 2002). This was clear in $Q$. ilex, the species with the highest CCI values and poorest fit, which showed a considerable dispersion of chlorophyll content data, especially above $70 \mathrm{CCI}$ units. Chlorophyll distribution has been shown to be more heterogeneous in high-chlorophyll than in low-chlorophyll leaves (Terashima and Saeki, 1983), which could explain the poorer performance of absorbance meters at high chlorophyll contents (Monje and Bugbee, 1992; Richardson et al., 2002).

\section{CONCLUSIONS}

The CCM-200 chlorophyll meter has proved to be a reliable nondestructive method to obtain an estimation of leaf chlorophyll contents in Mediterranean Quercus species. Only when readings were above 70 CCI were interpolations of data questionable. So, the CCM200 has good potential for use as a management tool to assess nutrient status in forest management. The present data show that calibrations should be leaf-age-specific owing to differences in the slopes of the CCI-chlorophyll content relationship; if not, interpretation of the data should be taken with caution when leaf samples of different developmental stages are used. Similarly, as shown in other studies, species-specific equations should be used to obtain a proper estimation of chlorophyll contents. However, when more general nonspecies-specific equations are of interest, the addition of fresh LMA as a complementary parameter can improve the accuracy of chlorophyll estimations. Nonetheless, although the estimation of fresh LMA is easy and cheap, it is a destructive technique that involves increased sampling efforts and more laboratory work.

Acknowledgements: This work received financial support from the University of Salamanca (Project No. 463AC01). M. Barquero-Palma assisted in the preparation of the protocols for chlorophyll extraction. We are grateful to J. Uddling and one anonymous reviewer for their helpful comments. Nicholas Skinner kindly corrected the English.

\section{REFERENCES}

Abadía A., Gil E., Morales F., Montañés L., Montserrat G., and Abadía J., 1996. Marcescence and senescence in a sub-Mediterranean oak (Quercus subpyrenaica E.H. del Villar): photosynthetic characteristics and nutrient composition. Plant Cell Environ. 19: 685-694.

Barnes J.D., Balaguer L., Manrique E., Elvira S., and Davison A.W., 1992. A reappraisal of the use of DMSO for the extraction and determination of chlorophylls a and $\mathrm{b}$ in lichens and higher plants. Environ. Exp. Bot. 32: 85-100.

Berg A.K. and Perkins T.D., 2004. Evaluation of a portable chlorophyll meter to estimate chlorophyll and nitrogen contents in sugar maple (Acer saccharum Marsh.) leaves. For. Ecol. Manage. 200: 113-117.

Campbell R.J., Mobley K.N., Marini R.P., and Pfeiffer D.G., 1990. Growing conditions alter the relationship between SPAD-5001 values and apple leaf chlorophyll. HortScience 25: 330-331.

Castelli F., Contillo R., and Miceli F., 1996. Non-destructive determination of leaf chlorophyll content in four crop species. J. Agron. Crop Sci. 177: 275-283.

Chang S.X. and Robinson D.J., 2003. Nondestructive and rapid estimation of hardwood foliar nitrogen status using the SPAD-502 chlorophyll meter. For. Ecol. Manage. 181: 331-338.

Daas C., Montpied P., Hanchi B., and Dreyer E., 2008. Responses of photosynthesis to high temperatures in oak saplings assessed by chlorophyll-a fluorescence: inter-specific diversity and temperatureinduced plasticity. Ann. For. Sci. 65: 305.

Datt B., 1999. A new reflectance index for remote sensing of chlorophyll content in higher plants: test using Eucalyptus leaves. J. Plant Physiol. 154: 30-36.

Gotelli N.J. and Ellison A.M., 2004. A primer of ecological statistics, Sinauer Associates, Inc., Sunderland, 528 p. 
Gratani L., Covone F., and Larcher W., 2006. Leaf plasticity in response to light of three evergreen species of the Mediterranean maquis. Trees 20: 549-558.

Haupt W. and Scheuerlein R., 1990. Chloroplast movement. Plant Cell Environ. 13: 595-614.

Hiscox J.D. and Israelstam G.F., 1979. A method for the extraction of chlorophyll from leaf tissue without maceration. Can. J. Bot. 57: $1332-1334$.

Hoel B.O. and Solhaug K.A., 1998. Effect of irradiance on chlorophyll estimation with the Minolta SPAD-502 leaf chlorophyll meter. Ann. Bot. 82: 389-392.

Jifon J.L., Syvertsen J.P., and Whaley E., 2005. Growth environment and leaf anatomy affect non-destructive estimates of chlorophyll and nitrogen in Citrus sp. leaves. J. Am. Soc. Hortic. Sci. 130: 152-158.

Markwell J., Osterman J.C., and Mitchell J.L., 1995. Calibration of the Minolta SPAD-502 leaf chlorophyll meter. Photosynth. Res. 46: 467472.

Mediavilla S. and Escudero A., 2003. Photosynthetic capacity, integrated over the lifetime of a leaf, is predicted to be independent of leaf longevity in some tree species. New Phytol. 159: 203-211.

Monge O.A. and Bugbee B., 1992. Inherent limitations of nondestructive chlorophyll meters: a comparison of two types of meters. HortScience 27: 69-71.

Moran J.A., Mitchell A.K., Goodmanson G., and Stockburguer K.A., 2000. Differentiation among effects of nitrogen fertilization treatments on conifer seedlings by foliar reflectance: a comparison of methods. Tree Physiol. 20: 1113-1120.

Neufeld H.S., Chappelka A.H., Somers G.L., Burkey K.O., Davison A.W., and Finkelstein P.L., 2006. Visible foliar injury caused by ozone alters the relationship between SPAD meter readings and chlorophyll concentrations in cutleaf coneflower. Photosynth. Res. 87: 281-286.

Peguero-Pina J.J., Morales F., and Gil-Pelegrín E., 2008. Frost damage in Pinus sylvestris L. stems assessed by chlorophyll fluorescence in cortical bark chlorenchyma. Ann. For. Sci. 65: 813.

Peñuelas J. and Filella I., 1998. Visible and near-infrared reflectance techniques for diagnosing plant physiological status. Trends Plant Sci. 3: $151-156$.

Pinkard E.A., Patel V., and Mohammed C., 2006. Chlorophyll and nitrogen determination for plantation-grown Eucalyptus nitens and $E$. globulus using a non-destructive meter. For. Ecol. Manage 223: $211-$ 217.
Porra R.J., 2002. The chequered history of the development and use of simultaneous equations for the accurate determination of chlorophylls $a$ and $b$. Photosynth. Res. 73: 149-156.

Richardson A.D., Duigan S.P., and Berlyn G.P., 2002. An evaluation of non-invasive methods to estimate foliar chlorophyll content. New Phytol. 153: 185-194.

Sibley J.L., Eakes D.J., Gilliam C.H., Keever G.J., Dozier W.A., and Himelrick D.G., 1996. Foliar SPAD-502 meter values, nitrogen levels, and extractable chlorophyll for red maple selection. HortScience 31: $468-470$.

Sokal R.R. and Rohlf F.J., 1995. Biometry, Freeman and Company, New York, $887 \mathrm{p}$.

Tait M.A. and Hik D.S., 2003. Is dimethylsulfoxide a reliable solvent for extracting chlorophyll under field conditions? Photosynth. Res. 78: 87-91.

Terashima I. and Saeki T., 1983. Light environment within a leaf. Plant Cell Physiol. 24: 1493-1501.

Thompson J.A., Schweitzer L.E., and Nelson R.L., 1996. Association of specific leaf weight, an estimate of chlorophyll, and chlorophyll concentration with apparent photosynthesis in soybean. Photosynth. Res. 49: $1-10$.

Uddling J., Gelang-Alfredsson J., Piikki K., and Pleijel H., 2007. Evaluating the relationship between leaf chlorophyll concentration and SPAD-502 chlorophyll meter readings. Photosynth. Res. 91: $37-46$.

Wang Q.B., Chen M.J., and Li Y.C., 2004. Nondestructive and rapid estimation of leaf chlorophyll and nitrogen status of peace lily using a chlorophyll meter. J. Plant Nutr. 27: 557-569.

Wellburn A.R., 1994. The spectral determination of chlorophylls $a$ and $b$, as well as total carotenoids, using various solvents with spectrophotometers of different resolution. J. Plant Physiol. 144: 307-313.

Wood C.W., Tracy P.W., Reeves D.W., and Edmisten, K.L., 1992. Determination of cotton nitrogen status with a hand-held chlorophyll meter. J. Plant Nutr. 15: 1435-1448.

Yamamoto A., Nakamura T., Adu-Gyamfi J.J., and Saigusa M., 2002. Relationship between chlorophyll content in leaves of sorghum and pigeonpea determined by extraction method and by chlorophyll meter (SPAD-502). J. Plant Nutr. 25: 2295-2301. 